\title{
Financial integration and total factor productivity: in consideration of different capital controls and foreign direct investment
}

\author{
Md Arif-Ur-Rahman* and Kazuo Inaba
}

\section{*Correspondence:} arif_rahman134@yahoo.com Graduate School of Economics, Ritsumeikan University, Noji Higashi 1-1-1 Kusatsu, Shiga 525-8577, Japan

\begin{abstract}
There is a long debate among policymakers and academicians regarding whether assessments of international financial integration have significant growth benefits and whether such benefits compensate for the accompanied risks. Recent financial crisis has revived this debate. The previous empirical studies have not been able to establish conclusive presumed benefits of financial integration for economic growth. This paper attempts to analyze the financial openness and total factor productivity (TFP) growth nexususing dynamic panel regression models for a substantial sample of countries ranging from year 1970 to 2014. Different measures of financial openness are incorporated in the dataset. We find evidence that financial integration is associated with higher TFP growth. A range of integration measures (both de jure and de facto) shows robust association with financial integration and TFP growth. The result also suggests that financial development might reduce the marginal effects of financial integration on TFP growth. This finding, however, appears to be influenced by the recent global economic turmoil and excessive private finance, especially in recent years.
\end{abstract}

Keywords: International financial integration, Total factor productivity, Financial development, Economic turmoil

JEL Classification: F41, F36, F15

\section{Introduction}

Cross-country financial flows are fundamental to international economics. There are hot debates among policymakers and academicians on the pros and cons of the current cross-border financial integration. In principle, financial integration enables an economy to borrow from foreign sources for financing domestic investment and also to increase access to advance technology and management skills, thus promoting productivity growth. However, this integration can also be blamed for being an important transmitter through which economic vulnerability spreads across economies. It also causes macroeconomic instability even financial crises. Recent financial turmoil directs policymakers to rethink appropriate financial opening policies for growth.

A vital issue in the debate of financial integration is whether openness to foreign capital has significant growth benefits and whether these benefits compensate for the

(c) The Author(s) 2020. This article is licensed under a Creative Commons Attribution 4.0 International License, which permits use, sharing adaptation, distribution and reproduction in any medium or format, as long as you give appropriate credit to the original author(s) and the source, provide a link to the Creative Commons licence, and indicate if changes were made. The images or other third party material in this article are included in the article's Creative Commons licence, unless indicated otherwise in a credit line to the material. If material is not included in the article's Creative Commons licence and your intended use is not permitted by statutory regulation or exceeds the permitted use, you will need to obtain permission directly from the copyright holder. To view a copy of this licence, visit http://creativeco mmons.org/licenses/by/4.0/. 
risks. In theory, there are a number of channels through which financial openness should affect economic performance. In a standard neo-classical framework, opening international capital markets generates capital flows from capital-abundant toward capital-scarce countries, thereby promoting growth in the poor countries through acceleration in the convergence process. While the industrial countries are capital affluent, the developing countries are relatively capital scarce; this fact should generate higher growth in developing economies and welfare gains for both groups. Nevertheless, there are few pieces of robust empirical evidence regarding a causal link between financial openness and economic growth. The majority of the studies tends to find no effect or, at best, mixed results. Quinn (1997), Vanassche (2004), Quinn and Toyoda (2008), and Gygli et al. (1999) evidence robust positive association between Capital account liberalization and economic growth. Whereas Kraay (1998), Rodrik (1998), Klein (2005), O’Donnell (2001), Durham (2004), Woo (2009), Alfaro et al. (2009), Baltabaev (2014), Milesi-Ferretti (2018), etc. do not find direct or casual link between financial openness and economic growth. In recent study, Lane and Milesi-Ferretti (2018) show the growth in cross-border positions in relation to world GDP has come to a halt. It documents the evolution of international financial integration since the global financial crisis.

Unlike a majority of the previous empirical studies, this paper attempts to change the direction of the financial openness and growth nexus debate by focusing on the consequence of financial openness on productivity growth rather than on economic growth. Several previous literatures on growth issues have shown that a large share of crosscountry differences in economic performance is obsessed by total factor productivity (TFP) rather than factor accumulation (physical and human capital). Hall and Jones (1999) conclude that GDP variation is mostly explained by variations in TFP. Klenow and Rodriguez-Clare (1997) also illustrate that GDP growth differentials are primarily caused by the differences in the growth rates of TFP. Bonfiglioli (2008) states that if financial integration only promotes capital accumulation and accelerates convergence, then its positive effect is expected to be short-lived. If instead, it raises TFP, it is most likely to stimulate long-term growth. Similarly, Bekaert et al. (2011) show that the impact of openness on TFP growth is more important than the effect on capital growth. They also explains why the growth effects of liberalization appear to be largely permanent rather than temporary. The literature on financial integration makes use of two distinctive groups of measures: de facto and de jure indicators. In particular, de jure indicators refer to the legal status of the financial liberalization process (Chinn and Ito 2008). De facto indicators measure the actual openness of financial transactions, usually expressed by stock, or flow ratios of assets, liabilities, the sum of both, or their components (FDI, portfolio investments, etc.) in the percentage to GDP (Gehringer 2013b). Most of the studies like Quinn (1997), Rodrik (1998), Edison et al. (2002a), Arteta et al. (2003), Quinn and Toyoda (2008), Bonfiglioli (2008), Lee (2016), etc. that examine the effects of financial integration have relied on de jure measures of capital account openness that reflect legal restrictions on capital movements. However, to realize the collateral benefits, de facto integration measures are also important. Because of the lack of enforcement, de jure indices of financial globalization do not reflect the actual extent to which the capital flows evolve in response to legal restrictions. Many countries have capital controls that are quite strict on document but that are roughly ineffectual in practice. Therefore, their 
de facto levels of integration-measured by capital flows or stocks of foreign assets and liabilities-are quite high. To address both regal restriction and actual extent of capital movement, this paper considers both de jure and de facto measures of openness.

A comprehensive analysis of the relationship between financial integration and productivity growth is conducted using a wide-range dataset that includes various measures (both de jure and de facto) of financial integration for a large number of developed and developing countries. In the baseline regression analysis, different capital control/openness indices (e.g., Di and $\mathrm{Ka})^{1}$ as de jure measures of integration and stock of foreign direct investment (FDI) relative to GDP as de-facto financial integration are considered. It is widely believed that FDI is the most stable form of capital inflows. Strong theoretical discussions and several pieces of empirical evidence suggest that FDI flows generate many of the indirect benefits of financial integration. This paper provides empirical evidence using dynamic panel regressions (system GMM and fixed effect) from a large sample of developed and developing countries observed over the period of 1970-2014. Based on the findings, this paper suggests that both de jure and de facto measures of financial integration matter for TFP growth after controlling for the usual determinants of growth. The findings are robust to alternative regression specifications and attempt to control for endogeneity.

Theoretical and empirical literature (Borensztein et al. 1998; Edwards 2001; Arteta et al. 2003; Durham 2004; Woo 2009; Alfaro et al. 2009; Baltabaev 2014, etc.) recently suggested that the absorptive capacity of a host country plays important roles in realizing the benefits of financial integration. To investigate whether the financial development of domestic economies has roles in realizing the benefits of financial integration, this research uses interaction terms of financial integration measures and a financial sector development indicator (private credit to GDP). The empirical results show that economies with better-developed financial markets do not necessarily benefit more from FDI in accelerating their economic growth, which is contrary to Alfaro et al. (2009). They find that countries with well-developed financial markets gain significantly from FDI via TFP improvements.

We use the dataset of capital control measures (2015) as de jure measure of capital control that is very new, and to the best of our knowledge, no published paper has used this dataset yet for the analysis of financial integration and TFP relationship. In addition to the basic analysis of international financial integration and TFP growth nexus, we focus more deeply on the role of financial development of the host economy in realizing the benefits of financial integration.

The next section reviews theoretical arguments and empirical evidence of the financial integration effects on economic growth and productivity growth. Section 3 discusses the empirical framework and estimation issues. Sect. 4 explains data, measures of different variables, and their sources. Section 5 shows the empirical findings followed by discussions of results. This paper concludes with a brief summary of the findings and their implications in Sect. 6 "Conclusion".

${ }^{1}$ Di: Direct Investment Control Index; Ka: Composite Capital Control Index. Source: Fernández et al. (2015) 


\section{Literature review}

\subsection{Theoretical arguments on financial integration and growth}

In neoclassical model, capital account opening assists an efficient cross-border allocation of funds. The funds flow from developed economies, where capital is abundant and the return to capital is low, to developing economies, where capital is scarce and the return to capital is high. The cost of capital reduces because of available flows of resources into the developing economies. As a consequence, the developing countries experience temporary increases in investment and growth through acceleration in the convergence process, thus this process permanently raises their standard of living (Fischer 1998, 2003; Obstfeld 1998; Rogoff, 1999; Summers 2000). This growth effect, however, is short-lived, since the steady state is not affected. The steady state or balance growth path can be achieved if poor countries' TFP-rather than solely capital accumulation-accelerates after financial liberalization (Bonfiglioli 2008). Motivated by the potential gains from integrating neo-classical argument into economic policies, many governments of developing countries, from Santiago to Seoul, have executed different forms of capital account liberalization Henry (2007).

If credit rationing were considered for the neo-classical framework above, productivity is likely to enhance to the extent that capital inflows make more productive investments possible by relieving the economy from credit constraints (as in Acemoglu and Zilibotti 1997). Bonfiglioli (2008) reports another approach where financial integration is considered similar to trade in goods. He argues, by exerting a pro-competitive effect on the capital markets, financial openness would persuade firms of all countries to use capital more efficiently, thereby raising productivity without necessarily causing capital flows across countries. He explains that financial integration-similar to trade in goods-could also promote specialization in financial services, which would develop allocative efficiency by allowing good firms to borrow at better conditions through specialized foreign intermediaries. Capital accumulation may eventually follow the increase in productivity.

Above arguments support the view that financial integration positively affects economic performance. However, several economists have disputed the positive effect in practice. Most of these economists base their arguments on the potential presence of other distortions stemming from the trade policy regime, macroeconomic policies, labor markets, information asymmetries, etc. They believe that financial integration could cause a misallocation of capital, and financial instability (as, for instance, in Rodrick 1998, and Stiglitz 2000), thereby negatively affects economic performance.

\subsection{Empirical evidence}

There is no consensus, regarding the direct effect of financial integration. Empirical studies yield very different results on the advantage of relative backwardness to benefit from integration. Given these inconsistencies in the literature, it is argued that there are several discrepancies among researchers who deal with both estimation and measurement in cross-country studies of the financial integration-growth nexus. Researchers have used various financial integration measures and yielded significantly incompatible results. The literature related to financial integration makes use of two distinctive groups 
of indicators measured for financial integration: de jure and de facto. There is an important difference between usual de jure measures of integration (i.e., restrictions/openness on capital account transactions) and de facto measures of integration.

The majority of previous empirical studies appear to be dominated by contributions focusing on the impact of financial integration on growth, as measured by changes of per capita GDP. However, there is a newly developing strand of the study that suggests indirect (rather than direct) sources of growth, and in particular, TFP growth could be the most important engines of dynamic and long-lasting economic performance. Moreover, the nature of the relationship between financial integration and TFP growth has important welfare implications, especially in light of recent literature emphasizing the role of TFP growth as a means to sustainable growth of per capita income. According to Hall and Jones (1999), consensus is developing that places more importance in TFP growth than factor accumulation.

The rest of this section is devoted to discussions on the most relevant earlier empirical works that examine links between financial integration and economic growth, and also between financial integration and TFP growth.

\subsubsection{Empirical evidence on financial integration and economic growth}

Rodrik (1998) conducted one of the first empirical studies to use the dummy variable for capital account openness from the IMF report. He reports that capital account liberalization has no significant effect on economic growth and the result supports that of an earlier study (Grilli and Milesi-Ferretti 1995). Rodrik's method is based on a binary measure of capital controls, which is a very coarse measure of financial integration. Utilizing a better and more informative version of the same de jure openness measure, Quinn and Toyoda (2008) find a positive relationship between capital account liberalization and economic growth. Using various measures of capital account openness including the Quinn index, Edwards (2001), Edison et al. (2002), Klein (2003) and Lee (2016) also find a positive association between capital account liberalization and economic growth. Dreher (2006) using own developed openness index (KOF Globalization Index) finds positive effect of financial globalization on economic growth. By revising and updating KOF globalization index, Gygli et al. (2019) find similar results.

The variations in the choices of the sample period, country coverage, empirical methodology, and the measure of integration cause the notably different estimated results across studies. For instance, Rodrik's (1998) analysis covers the period from 1975 to 1989. On the other hand, Quinn and Toyoda's (2008) sample covers a longer period, 1955-2004. For studying the relationship between economic growth and financial integration, longer time lengths are presumably more appropriate. Using both cross-section and panel regression methodology, Lee (2016) finds that capital account liberalization and growth have a positive correlation in panel regressions, which demonstrates the temporary positive effects of financial opening on economic growth within a country.

Few authors argue that positive impact of capital opening on economic growth is confined only to the developing countries. Others have found that the impact tends to be open to all groups of countries: advanced, emerging, and other developing. Edwards (2001), Klein (2003) and Edison et al. (2004) report that capital account liberalization has a positive growth effect in middle-income developing countries, whereas Quinn (1997), 
Arteta et al. (2003) and Quinn and Toyoda (2008) report uniform results for all groups of countries.

Specifications of de facto measures-compared to de jure measures-of financial integration tend to give more support for the potential growth, thus enhancing positive effects of financial integration. Kraay (1998), O’Donnell (2001), Edison et al. (2002b) and Garita (2009) have similar findings. Effects on growth differ according to the types of capital flows. FDI and portfolio equity flows are steady in nature and alleged to fetch many indirect benefits.

\subsubsection{Empirical evidence on financial integration and total factor productivity growth}

Bonfiglioli (2008) offers one of the first empirical works that contribute to the comprehensive assessment of the productivity growth channel. Two main channels of growth, TFP and investment, are discussed in her study. She checked the impact of financial integration on both of the channels. The result suggests that there is a significantly positive impact of financial integration on TFP growth, but not for capital accumulation or investment. Gehringer (2013a) also finds similar findings for the sample of the EU countries. Using both de jure and de facto measures of integration, he concludes that the EU integration is supportive to the financial impact on productivity, whereas the euro adoption is not. The analysis was based on $26 \mathrm{EU}$ members between 1990 and 2007 and the difference GMM (generalized method of moments) is used as the empirical method. Levchenko et al. (2009), however, find only a short-run effect of financial integration on industry-level TFP. Bekaert et al. (2011) state that compared to the impact of openness on capital growth, the effect on factor productivity growth is more imperative. Further, the growth effects of liberalization appear to be permanent rather than temporary.

Kose et al. (2008a) conduct a wide-ranging analysis of the association between financial integration and TFP growth using both measures of financial integration-de jure and de facto. While they find a positive significant effect of capital openness indices on TFP growth, the effect of de facto financial integration on TFP growth is less clear when total liabilities and assets are used as a proxy of de facto measure. However, when they disaggregate the financial integration measure into stocks of liabilities attributable to different types of underlying capital flows, they find strong support that FDI and portfolio equity flows improve TFP growth.

Though the theory suggests that financial integration can benefit an economy, empirical evidence is very divergent. These divergences of empirical results are influenced by the differences in the measurement of integration, choice of empirical methodology, country-specific characteristics, availability of data, etc. Thus, the major conclusion is that evidence based on cross-country regression frameworks has been inconclusive. In some respect, the conceptual or theoretical constraints cannot be defeated only using econometric tools, techniques and quality of cross-country data.

\section{Empirical methodology and framework}

This section discusses some issues that need to be confronted in empirical analysis and also explains how to deal with them. The empirical framework builds on standard crosscountry growth regressions to capture the effect of financial integration on TFP growth at the national level. Dynamic panel regression framework is used in this study. Though 
this approach has some drawbacks, it provides a clear depiction of the effects of financial integration on TFP growth at the macro-level. Dynamic panel methods on cross-country data need to be contended with conceptual and econometric issues.

The conceptual issue relates to the idea argued by Henry (2007) that capital account liberalization should only have a temporary positive effect on productivity growth. This idea may be analytically acceptable, and it is also true that the transition to a new steady state could take a long time, especially for economies that are distant from the technology frontier. Agenor et al. (2000) and Aguiar and Gopinath (2007) argue that business cycles are more persistent in developing economies than in industrial ones, so a 5-year window is a reasonable compromise for filtering out cycles in both developing and industrial countries. This study focuses on comparatively low-frequency data (5-year average) rather than high-frequency data (year-to-year) to remove very shortterm effects and also to examine whether financial integration has a sustained effect on productivity growth. Therefore, this study is a pertinent scope, not only just for capturing more than simply temporary and business cycle effects, but also for indicating the significance of financial integration in generating productivity take-off.

One of the econometric issues of concern is that of reverse causality: the likelihood that higher productivity growth attracts more foreign capital and the associated problem of endogeneity. The productivity growth and capital inflows could both be responding to some other forces. Prasad et al. (2007) find that, despite evidence of rising net flows of capital from developing to industrial countries, capital flows-especially FDI-do tend to follow productivity growth. Gourinchas and Jeanne (2007) reveal that among developing countries, net capital inflows are negatively correlated with productivity growth, which is evidence against the type of reverse causality. Unfortunately, it is difficult to find a proper instrument at the country level that influences financial integration yet not TFP growth. Therefore, we deal with the endogeneity issue, in the presence of unobserved country fixed effects, using the System GMM approach of Blundell and Bond (1998). System GMM uses appropriate lagged levels and lagged first differences of the regressors as instruments. This is admittedly a mechanical approach to deal with endogeneity, but it sounds as an econometric method. It controls an unobserved country-specific term because the first difference of the data series has to be taken to execute the estimator and it eliminates the unobserved country-specific term. The system GMM is also able to control for the potential endogeneity of all the explanatory variables, including the lagged dependent variable, as an instrument. As the specification test for system GMM, the Hansen over-identification test is used to check the validity of instruments and the Arellano-Bond AR (2) test is used to measure the second-order serial correlation. In addition to system GMM, basic fixed effect estimation is also conducted as a consistency check.

Of course, the level of financial integration has evidently changed over time. To exploit the time series variation in the data, dynamic panel regressions are estimated based on 5-year average for each country. The baseline regression specification is as follows:

$$
\Delta \ln \operatorname{TFP}_{i, t}=\alpha+\beta \operatorname{lnTFP} i_{i, t-1}+\gamma \mathrm{FI}_{i, t}+\lambda Z_{i, t}+\mu_{t}+\eta_{i}+\varepsilon_{i, t} .
$$

Equation (1) specifies the relationship of financial integration to TFP. Here, $\Delta \ln T_{F} P_{i, t}$ is the $\log$ growth of TFP, $\operatorname{lnTFP}_{i, t-1}$ is the level of TFP at the beginning of each 5 -year 
Table 1 Variable definitions and data sources

\begin{tabular}{lll}
\hline Variables & Definition & Source \\
\hline TFP & Log of TFP & PWT 9.0 \\
Initial TFP & Log of TFP from previous period & PWT 9.01 \\
GDP & Log of GDP per capita, in constant 2010 U.S. dollars & WDI \\
Initial GDP & Log of GDP per capita from previous period & WDI \\
FDI & Foreign direct investment, stock (\% of GDP) & Lane and Milesi-Ferretti (2007) \\
FDI flow & Foreign direct investment, net inflows (\% of GDP) & WDI \\
Di & Direct investment restrictions & 'Capital control measures: a \\
Ka & Overall capital restrictions index (all asset categories) & Same dataset'- IMF \\
KAOPEN & Capital account openness index (Chinn-Ito index) & Chinn and Ito 2006) \\
CAPITAL & Capital account openness index (Quinn Index) & Quinn (1997) \\
Schooling & Average years of secondary schooling (for the population & Barro and Lee (2013) \\
Pvt. cr & over 15 years of age) & \\
Pvt. cr_bank & Domestic credit to private sector (\% of GDP) & WDI \\
Pop. growth & Private credit by deposit money banks (\% of GDP) & WDI \\
Investment & Population growth (annual \%) & WDI \\
\hline
\end{tabular}

period, $Z_{i, t}$ represents the set of relevant control variables, $\mu_{t}$ symbolizes time dummies (for each non-overlapping 5-year period), $\eta_{\mathrm{i}}$ stands for country fixed effects, $\varepsilon_{i, t}$ is error terms, and finally, $\mathrm{FI}_{\mathrm{i}, \mathrm{t}}$ is the set of financial integration/openness measures. The " $i$ " indexes the country and " $t$ " the time period. Most explanatory variables are treated as endogenous, and the time trend is treated as strictly exogenous.

To empirically assess the effect of interactive terms between financial integration measures and financial development on productive growth, this paper utilizes the following specification:

$$
\Delta \ln \mathrm{TFP}_{i, t}=\alpha+\beta \operatorname{lnTFP} \mathrm{i}_{\mathrm{i}, t-1}+\gamma \mathrm{FI}_{i, t}+\delta\left(\mathrm{FI}_{i, t} * \mathrm{FD}_{i, t}\right)+\lambda \mathrm{Z}_{i, t}+\mu_{t}+\eta_{i}+\varepsilon_{i, t} .
$$

FI represents the measure of financial integration and FD financial development indicators (Private credit/GDP in baseline case) of the host country. Other specifications are same as Eq. (1).

\section{Measurement and data}

This section confers the approach to several key measurement issues and presents the dataset. For measurement and analysis, various data sources are utilized including the World Development Indicators, the latest version of the Penn World Tables (PWT, Version 9.0, Feenstra et al. 2015), and other databases maintained and developed by the World Bank and other authors. The dataset comprises annual data over the period 19702014 for 108 countries. A detailed description of the variables and their data sources is presented in Table 1.

\subsection{Total factor productivity (TFP)}

Consider the standard Cobb-Douglas production function written as: 


$$
\mathrm{Y}=\mathrm{AK}^{\alpha}(\mathrm{HL})^{1-\alpha}
$$

where $\mathrm{Y}$ denotes aggregate output, $\mathrm{A}$ is the stock of knowledge or TFP, $\mathrm{K}$ and $\mathrm{H}$ indicate the stocks of physical and human capital, respectively, and $\mathrm{L}$ is the number of workers. The aggregate output growth will depend on the rate of change of these four factors. To calculate TFP, we need time series data on $\mathrm{Y}, \mathrm{K}, \mathrm{H}$, and L, and also an estimation of the parameter ' $\alpha$. Here, ' $\alpha$ ' is the share of physical capital in total national income. The growth rate of TFP, which is obtained as residuals in the growth accounting, is often recognized as technological progress. TFP can change for many reasons, such as where there is an increase in stock of knowledge about production techniques. The endogenous growth theory focuses on technological progress as a consequence of intentional industrial innovation through R\&D activities in response to their expected profits. Both the costs of $R \& D$ and the rewards, which innovators gain, are influenced by conditions in product (including market size), factor (such as skilled labor), and capital markets, as well as government policies and institutions that administrate these market conditions.

The analysis utilizes TFP from the Penn World Table (PWT) 9.0. TFP values are at constant national prices $(2011=1)$. For TFP growth, the growth of log TFP is calculated over each 5 -year period in the equation.

$$
\Delta \ln \mathrm{TFP}_{i, t}=\ln \mathrm{TFP}_{i, t}-\ln \mathrm{TFP}_{i, t-5} .
$$

\subsection{Financial integration measures}

There is no wide consensus in the literature regarding the choice of an appropriate measurement of financial integration. As mentioned earlier, the literature on financial integration uses two distinct measures: de facto and de jure indicators. There is an important difference between traditional de jure measures of integration and de facto measures of integration. Capital controls are the relevant policy tools, but there can be differences in their degree of enforcement over time. In view of these theoretical concerns and the controversy surrounding the selection of the appropriate measure, the impact of both types of financial integration measures, de jure and de facto, is examined in this analysis.

In our baseline model, two de jure measures of financial integration are used: the overall capital restriction index $(\mathrm{Ka})$ and the direct investment restrictions (Di) of IMF new capital control measure. The overall restrictions index (Ka) and the direct investment restriction $(\mathrm{Di})$ are chosen from the very recent capital controls dataset ${ }^{2}$ by Fernández, Klein, Rebucci, Schindler, and Uribe (2015). This dataset is prepared based on the work of Schindler (2009) and the IMF's Annual Report on Exchange Arrangements and Exchange Restrictions (AREAER). It includes capital control measures on both inflows and outflows of 10 categories of assets for 100 countries over the period of 1995 to 2014. The covered asset categories are money market, equities, collective investments, derivatives, financial credits, real estate, commercial credits, guaranties, sureties and financial backup facilities, and direct investment. In addition, to check the robustness of the basic findings, two other well-known openness indexes

\footnotetext{
2 The dataset is available for download at http://www.nber.org/data/international-finance/.
} 
are also used: Chinn and Ito's (2006) capital account openness index (KAOPEN) and Quinn's (1997) openness index (CAPITAL).

The baseline measure of de facto financial integration is the ratio of stocks of foreign direct investment (FDI) to GDP, a cumulated measure of inflows. FDI better suits the concept of openness to foreign capital than other forms of cross-border capital flows. FDI is measured over 5-year averages as a stock of FDI over GDP. The stock variable is preferred over flow as it measures already established foreign firms rather than newly arrived ones. Many studies (Alfaro et al. 2004; Carkovic and Levine 2005; Woo 2009, etc.) consider FDI flows to GDP rather FDI stock. In general, business cycle fluctuation may cause FDI flows to be volatile. The impact of foreign capital on an economy's TFP growth might defer because of FDI measurement (stock vs. flow). Therefore, per theory, a positive impact of FDI on TFP growth can be expected.

FDI stock data are sourced from the "updated and extended version of the External Wealth of Nations Mark II database" developed by Lane and Milesi-Ferretti (2007). They construct estimates of external assets and liabilities for 188 countries for the period of 1970-2014. The estimates heavily rely on information published by individual countries and international organizations (such as the IMF, the World Bank, and the Bank for International Settlements). For our analysis, FDI liability for countries, which is equivalent to inward FDI stock, is used. For robustness check, FDI flow over GDP is also considered. FDI flow data are taken from the World Development Indicators (WDI) of the World Bank.

\subsection{Other control variables}

When assessing the effects of financial integration on TFP, a number of factors are used as control variables, such as human capital, investment, population growth, financial development, etc. For human capital (yr_sch_sec), this paper uses the average years of secondary schooling (for the population over 15 years of age) constructed by Barro and Lee (2013). It is measured in 5-year averages. We also control gross capital formation (\% of GDP) as a proxy of investment. The ratio of private-sector credit by overall financial system to GDP is used as a rough measure of financial development. Though this measure has several shortcomings, the ratio of private-sector credit to GDP is used because it has the advantage of being available on a reasonably consistent basis for a long period of time and for a large number of countries. Privatesector credit by deposit money banks is also examined as an alternative measure of financial depth and development.

\section{Empirical findings}

First, we discuss the basic findings on the relationship of financial integration and TFP growth. Second, we examine how the financial development of the host country plays a role in comprehending the benefits of financial integration. Finally, the main analysis is extended by exploring the impact of financial integration to different income level groups and also by examining the robustness of the basic findings including alternative variables. 
Table 2 Financial integration and TFP growth: panel regressions (dependent variableTFP growth; 5-year panel)

\begin{tabular}{|c|c|c|c|c|c|c|}
\hline \multirow[t]{2}{*}{ Variables } & \multicolumn{3}{|l|}{ Fixed effect } & \multicolumn{3}{|c|}{ System GMM } \\
\hline & (1) & $(2)$ & (3) & (4) & (5) & (6) \\
\hline \multirow[t]{2}{*}{ Initial TFP } & $-0.6947^{* * *}$ & $-0.6908^{* * *}$ & $-0.5009^{* * *}$ & $-0.4548^{* * *}$ & $-0.4195^{* * *}$ & $-0.3217^{* * *}$ \\
\hline & $(0.0643)$ & $(0.0632)$ & $(0.0315)$ & $(0.1468)$ & $(0.1186)$ & $(0.0525)$ \\
\hline \multirow[t]{2}{*}{ Schooling } & $0.0471^{* * *}$ & $0.0506^{* * *}$ & $0.0172^{*}$ & $0.0462^{*}$ & 0.0358 & $0.0450^{* * *}$ \\
\hline & $(0.0159)$ & $(0.0156)$ & $(0.0104)$ & $(0.0274)$ & $(0.0274)$ & $(0.0131)$ \\
\hline \multirow[t]{2}{*}{ Investment } & $0.0079^{* * *}$ & $0.0074^{* * *}$ & $0.0071^{* * *}$ & $0.0123^{* * *}$ & $0.0124^{* * *}$ & $0.0105^{* * *}$ \\
\hline & $(0.0018)$ & $(0.0017)$ & $(0.0009)$ & $(0.0040)$ & $(0.0037)$ & $(0.0022)$ \\
\hline \multirow[t]{2}{*}{ Population } & -0.0834 & -0.0999 & $-0.1916^{* * *}$ & -0.0067 & -0.0349 & -0.0197 \\
\hline & $(0.0679)$ & $(0.0666)$ & $(0.0297)$ & $(0.0537)$ & $(0.0545)$ & $(0.0242)$ \\
\hline \multirow[t]{2}{*}{ Pvt. credit } & 0.0006 & 0.0006 & 0.0004 & 0.0015 & $0.0018^{*}$ & 0.0008 \\
\hline & $(0.0004)$ & $(0.0004)$ & $(0.0003)$ & $(0.0010)$ & $(0.0010)$ & $(0.0005)$ \\
\hline \multirow[t]{2}{*}{ Ka } & $-0.0790^{*}$ & & & $-0.2057^{* * *}$ & & \\
\hline & $(0.0476)$ & & & $(0.0642)$ & & \\
\hline Di & & $\begin{array}{c}-0.0971^{* * *} \\
(0.0335)\end{array}$ & & & $\begin{array}{c}-0.1281^{* *} \\
(0.0526)\end{array}$ & \\
\hline FDI Stock & & & $\begin{array}{r}0.0502^{* * *} \\
(0.0066)\end{array}$ & & & $\begin{array}{r}0.0601^{* * *} \\
(0.0121)\end{array}$ \\
\hline Observations & 272 & 272 & 608 & 272 & 272 & 608 \\
\hline R-squared & 0.4345 & 0.4517 & 0.4247 & & & \\
\hline No. of countries & 78 & 78 & 109 & 78 & 78 & 109 \\
\hline \multicolumn{7}{|c|}{ Specification test ( $p$ value) } \\
\hline \multicolumn{2}{|l|}{ Hansen OID } & & & 0.835 & 0.495 & 0.372 \\
\hline \multicolumn{2}{|l|}{$\operatorname{AR}(2)$} & & & 0.475 & 0.395 & 0.225 \\
\hline \multicolumn{2}{|c|}{ No. of instruments } & & & 43 & 43 & 52 \\
\hline
\end{tabular}

1. The dependent variable is the growth rate of TFP over each 5-year period. 2 . All standard errors are robust and reported in parentheses. 3. Statistical significance: ${ }^{* *} p<0.01,{ }^{* *} p<0.05,{ }^{*} p<0.1$. 4. Intercept not reported. 5. All regressions include time dummies. 6. For variables, see Table 1

\subsection{Basic findings on financial integration and TFP growth}

Table 2 exhibits the empirical relationship between different measures (both de jure and de facto) of financial integration and TFP growth in the presence of other growth control variables. The first panel (columns 1-3) of Table 2 presents the results of fixed effects (FE) panel regressions and the second panel (columns 4-6) presents the results of system GMM panel regressions.

The first two columns of each panel show the impact of two de jure measures (Ka and Di; capital control measures of Fernández et al 2015) of financial integration on TFP growth. The third column reveals the effect of the de facto measure (FDI Stock/ GDP). In the first panel, the coefficients of Ka and Di are negative and significant to TFP growth. The signs of the coefficients are as expected. The estimated result implies that presence of restrictions or controls on overall capital (Ka) and direct investment (Di) reduces the TFP growth. The coefficients are significant at $90 \%$ and $99 \%$ level of confidence, respectively. These results exhibit restriction on capital flows and restrain TFP. The estimated coefficients of Ka and Di imply that the economy that has restrictions on capital flows over a 5 -year horizon annual TFP growth is about 8 and 10\% lower than an economy that has no controls on capital flows. 
Using the IMF binary variable provided by the Annual Report on Exchange Arrangements and Exchange Restrictions (AREAER) as an openness measure, different studies find diverse results regarding the relationships between openness and growth. Use of IMF_BINARY indicators has many problems. For example, Quinn (2008) quotes from Voth (2003, p. 271), "Along with other authors, we find that the inability of earlier studies to find a significant effect of capital controls on most economic control variables was caused by the use of simple dichotomous variables as indicators for capital controls." In our analysis, the capital control variables Ka and Di are extrapolated from the AREAER reports of IMF, but these are not binary ${ }^{3}$ coding indexes. Ka is the overall restriction index which is the average of all asset categories' ${ }^{4}$ inflow and outflow restriction index. Likewise, Di is the average of the direct investment restriction index. By utilizing a better and more informative version of de jure openness measure, we find that capital openness/restriction matters for TFP growth. The results suggest that overall capital control has a significant impact on TFP growth of an economy. Very few studies have analyzed the de jure financial integration and factor productivity growth nexus. Our findings are in line with the work of Bonfiglioli (2008) and Kose et al. (2008a). Both of the studies conduct a broad analysis of the relationship between financial openness and TFP growth. As a measure of financial liberalization, both papers use IMF binary variable of AREAER and conduct dynamic panel regression. They find that de jure capital account liberalization has a robust positive effect on TFP growth.

In the third column, we find that the de facto measure of financial integration, FDI stock, has a significant (at 1\% level) positive effect on TFP growth after controlling for different control variables such as initial TFP, schooling, population growth, gross investment, and private-sector credit. The initial TFP estimate confirms the evidence of conditional convergence in productivity as it is consistently significant in all specifications. Human capital (schooling) shows positive associations with TFP. Investment also has a positive significant effect on the growth of TFP. First focusing in the fixed effect (FE) results, a 1\% increase in the ratio of FDI to GDP would be associated with about a $5 \%$ increase in annual TFP growth over a 5 -year period. As discussed earlier, a large body of theoretical and empirical evidence suggests that FDI, in particular, generates many of the indirect benefits of financial integration. Our findings also clearly indicate that FDI is an important means of financial integration through which an economy can enhance TFP growth and thereby economic growth also. These results are in contrast with the findings of Carkovic and Levine (2005), Alfaro et al. (2009), Durham (2004) and AzmanSaini et al. (2010). They do not find any direct positive effect of FDI on growth. This difference in results may come from the different estimation methods, samples, periods, and also different specifications of variables. The results support the empirical findings of Kose et al. (2008a), Woo (2009), and Baltabaev (2014), which reveal direct positive significant effects of FDI on TFP growth.

Carkovic and Levine (2005) find that FDI has no significant effect on economic growth. Initially, they find a positive association between FDI and economic growth; the association disappears when they control for other variables. They also do not find a

\footnotetext{
${ }^{3} 0=$ no control, $1=$ control.

${ }^{4}$ Capital controls dataset by Fernándezet al. (2015) has 10 categories of asset mentioned in Chapter 4.
} 
significant relationship between FDI and TFP growth. Similar to our study, they also use a 5-year panel regression, but their variable specification and period under consideration are different. They cover cross-county data from 1960 to 1995 . Contrary to our findings, Alfaro et al. (2009) also suggest that foreign direct investment has no direct impact on a country's TFP growth, but they find an indirect positive effect through more financial development. Compared to our analysis, they consider a smaller sample size (62 countries) and time period (1975-1995) and also adopt simple cross-section OLS strategy rather dynamic panel. Cross-sectional regression is criticized for its inability to capture the time-varying effects of independent variables. As a result, it cannot retain the shortterm effects of financial integration. ${ }^{5}$

Our findings support the comprehensive analysis of Kose et al. (2008b). They find strong evidence that FDI and portfolio equity liabilities boost TFP growth using dynamic panel regression of wide dataset (1966-2005).

As mentioned earlier, a major concern about such regressions is that TFP growth and financial integration measures may be endogenous. When endogeneity is controlled for using the system GMM estimator, the results in the second panel (columns 4-6) of Table 2 illustrate similar findings with different magnitude. The fixed effect estimated results show that the coefficient of Ka and Di is negative and FDI stock is positive and statistically significant to TFP growth. In the second panel, the Hansen test supports the validity of instruments at conventional levels of statistical significance. ${ }^{6}$ The insignificant second-order correlations in all columns suggest that there is an absence of serial correlation in the error terms.

\subsection{Role financial integration and financial development on TFP growth}

A large number of recent theoretical and empirical studies suggest that absorptive capacities or initial conditions of the host country play essential roles in apprehending the benefits of financial integration. There is lack of consensus among studies regarding the question of what primary conditions are considered necessary to set up the ground for financial integration to generate growth benefits and lower the risks. The interaction of financial integration measures and financial development is used in this paper to check the conditional effect of financial integration on TFP growth.

Table 3 exhibits the results of interaction terms of financial integration measures and private credit to GDP (Pvt. credit) as an indicator of financial development. In the first two columns, we find that the interactions of de jure measures (Ka \& Di) and private credit have significant positive influence on TFP growth of a nation. The positive significant coefficient of interaction terms reveals that an economy with high capital and direct investment restriction can ensure high TFP growth by ensuring financial development. The restriction on capitals flows has negative effect on TFP growth; this negative effect might be alleviated by the high level of private credit, the measure of developed financial market. This finding contradicts the theoretical assumption that a country with

\footnotetext{
5 Though not reported, we also test the cross-section OLS for the similar variables and find insignificant results.

${ }^{6}$ If the most explanatory variables are considered as exogenous following the usual (most simplistic way) system GMM specification, the Hansen Over identification test results invalidate the instruments. Following Kose et al. (2008a), most explanatory variables are treated as endogenous, and the time trend as strictly exogenous. This specification confirms the validity of instruments by Hansen Over identification test.
} 
Table 3 Conditional effect and TFP growth: fixed effect (dependent variable-TFP growth; 5-year panel)

\begin{tabular}{|c|c|c|c|c|}
\hline Variables & (1) & $(2)$ & (3) & (4) \\
\hline \multirow[t]{2}{*}{ Initial TFP } & $-0.7141^{* * *}$ & $-0.7100^{* * *}$ & $-0.4993^{* *}$ & $-0.4988^{* * *}$ \\
\hline & $(0.0629)$ & $(0.0620)$ & $(0.0332)$ & $(0.0331)$ \\
\hline \multirow[t]{2}{*}{ Schooling } & $0.0397^{* *}$ & $0.0530^{* * *}$ & $0.0264^{* *}$ & $0.0280^{* *}$ \\
\hline & $(0.0159)$ & $(0.0155)$ & $(0.0110)$ & (0.0108) \\
\hline \multirow[t]{2}{*}{ Investment } & $0.0072^{* * *}$ & $0.0073^{* * *}$ & $0.0078^{* * *}$ & $0.0077^{* * *}$ \\
\hline & $(0.0018)$ & $(0.0018)$ & $(0.0010)$ & $(0.0010)$ \\
\hline \multirow[t]{2}{*}{ Population } & -0.0741 & $-0.1181^{*}$ & $-0.1349^{* * *}$ & $-0.1370^{* * *}$ \\
\hline & $(0.0684)$ & $(0.0665)$ & $(0.0297)$ & (0.0298) \\
\hline \multirow[t]{2}{*}{ Pvt. credit } & -0.0002 & -0.0002 & $0.0010^{* * *}$ & \\
\hline & $(0.0005)$ & $(0.0005)$ & $(0.0003)$ & \\
\hline \multirow[t]{2}{*}{ Pvt. credit_bank } & & & & $0.0010^{* * *}$ \\
\hline & & & & $(0.0003)$ \\
\hline \multirow[t]{2}{*}{$\mathrm{Ka}$} & $-0.2152^{* * *}$ & & & \\
\hline & $(0.0627)$ & & & \\
\hline \multirow[t]{2}{*}{ Ka*Pvt. credit } & $0.0029^{* * *}$ & & & \\
\hline & $(0.0008)$ & & & \\
\hline \multirow[t]{2}{*}{ Di } & & $-0.2233^{* * *}$ & & \\
\hline & & $(0.0506)$ & & \\
\hline \multirow[t]{2}{*}{ Di*Pvt. credit } & & $0.0020^{* * *}$ & & \\
\hline & & $(0.0006)$ & & \\
\hline \multirow[t]{2}{*}{ FDI } & & & $0.0017^{* * *}$ & $0.0017^{* * *}$ \\
\hline & & & $(0.0005)$ & $(0.0005)$ \\
\hline \multirow[t]{2}{*}{ FDI*Pvt. credit } & & & $-0.0000128^{* * *}$ & \\
\hline & & & $(0.0000)$ & \\
\hline \multirow[t]{2}{*}{ FDI*Pvt.credit_bank } & & & & $-0.0000124^{* * *}$ \\
\hline & & & & $(0.0000)$ \\
\hline Observations & 267 & 267 & 602 & 601 \\
\hline R-squared & 0.4764 & 0.4901 & 0.3776 & 0.3776 \\
\hline Number of countries & 77 & 77 & 108 & 108 \\
\hline
\end{tabular}

1. The dependent variable is the growth rate of TFP over each 5 -year period. 2 . All standard errors are robust and reported in parentheses. 3. Statistical significance: ${ }^{* * *} p<0.01,{ }^{* *} p<0.05,{ }^{*} p<0.1$. 4. Intercept not reported. 5. All regressions include time dummies. 6 . For variables, see Table 1

developed financial markets significantly benefits from financial openness in terms of TFP growth. Here, we find that a country with a high level of private credit significantly benefits from financial restrictions rather than financial openness. In fact, the estimates of interaction terms with the de jure measure might not always be dependable because capital controls are the relevant policy tool. However, there can be differences in their intensity of enforcement over time, while many countries have capital controls that are quite strict on paper, but ineffective in practice. For example, the index value of Ka and Di for China and India is very high (about 1). The high index value indicates a high level of control for capital and direct investment flow; however, in practice, both countries have high levels of inward FDI flow.

Focusing on the estimates in column 3 of Table 3, the basic coefficient of FDI is preserved as positive significant. With regard to interaction terms, we find an interesting result that the coefficient of interaction between private-sector credit and the FDI stock 
is negatively significant (at 5\% level of significance). That is, a high level of private-sector credit might reduce the marginal effect of FDI on TFP growth. Though the coefficient of the interaction term is significant, the extent of effect is very nominal as the coefficient size is quite small (only $0.00128 \%$ ). In column 4 , an alternative measure of financial development is used: the ratio of private-sector credit by deposit money banks to GDP (Pvt.credit_bank). The interaction terms of FDI and private credit by deposit money banks hold similar results; that is, a significantly (at $5 \%$ level of significance) negative association with TFP growth. These findings contrast the work of Alfaro et al. (2009), who find that in countries with a high level of private credit, the measure of developed financial markets significantly benefits from FDI in terms of TFP growth. They adopt a simple cross-section OLS strategy over the period of 1975-1995 for 62 countries. They measured FDI as the share of inward FDI flows in GDP and sourced from the IMF publication entitled "International Financial Statistics" (IFS). Contrary to Alfaro et al. (2009), this paper uses dynamic penal regression over a longer time period (1970-2010) for more than 100 countries. Moreover, we use inward FDI stocks rather than flow to check the volatility that arises from the business cycle. Using 10-year average panel regression, Kose et al. (2008b) also find negative coefficient for the interaction of private credit to GDP and stock value of inward FDI and portfolio equity regarding TFP growth. Their result was insignificant. As mentioned earlier, empirical results across studies differ possibly because of the differences in the sample period, country coverage, choice of empirical methodology, and the measure or specification of integration. It is argued that cross-sectional regressions cannot capture the time-varying effects of independent variables or detain the short-term effects of financial integration.

Besides the empirical methodology, coverage of the time period and specification of variables, other concerns, such as macro-economic condition, can also cause differences in results. The recent global economic crisis (2007-2008) demonstrated that malfunctioning financial systems can directly and indirectly waste resources, discourage saving, and encourage speculation, then result in underinvestment and a misallocation of scarce resources. Adverse implications of financial turmoil and the extreme falls in real sector activity during the crisis emphasize the need for economists and policy makers to decide the optimal size of financial systems for sustainable economic growth. Financial sectors grew rapidly over the 2000-2010 period. The 5-year average of private-sector credit to GDP increased from 36\% in 1991-1995 to 53\% in 2005-2010. Arcand et al. (2012) report that the number of countries in which private credit was greater than $90 \%$ of GDP increased from 4 to $22 \%$ of the total in the period between 1985 and 2005. On the other hand, TFP growth fell dramatically throughout the crisis, mostly in developed countries. As a consequence of the high level of private credit, the issue of non-linearity between financial development and growth became very popular among authors, especially after the 2007-2008 global economic crises. Arcand et al. (2012) argue that there is a threshold above which financial development no longer has a positive effect on economic growth. They use different empirical approaches to show that there can indeed be "too much" finance. Using a panel error correction model, Loayza and Ranciere (2006) present interesting findings regarding a negative short-run and positive long-run association between financial development and economic growth. Financial crises are the main cause of the negative short-run relationship. The negative relationship between the 
Table 4 Robustness check: financial integration and tfp growth-panel regressions (dependent variable-TFP growth; 5-year panel)

\begin{tabular}{|c|c|c|c|c|c|c|}
\hline \multirow[t]{2}{*}{ Variables } & \multicolumn{3}{|l|}{ Fixed effect } & \multicolumn{3}{|c|}{ System GMM } \\
\hline & (1) & (2) & (3) & (4) & (5) & (6) \\
\hline \multirow[t]{2}{*}{ Initial TFP } & $-0.4854^{* * *}$ & $-0.3962^{* * *}$ & $-0.4424^{* * *}$ & $-0.3125^{* * *}$ & $-0.2297^{* * *}$ & $-0.2289^{* * *}$ \\
\hline & $(0.0333)$ & $(0.0460)$ & $(0.0337)$ & $(0.0774)$ & $(0.0876)$ & $(0.0755)$ \\
\hline \multirow[t]{2}{*}{ Schooling } & $0.0228^{* *}$ & 0.0145 & $0.0218^{* *}$ & $0.0275^{*}$ & $0.0277^{*}$ & $0.0290^{* *}$ \\
\hline & $(0.0112)$ & $(0.0150)$ & $(0.0109)$ & $(0.0144)$ & $(0.0147)$ & $(0.0129)$ \\
\hline \multirow[t]{2}{*}{ Investment } & $0.0083^{* * *}$ & $0.0043^{* * *}$ & $0.0069^{* * *}$ & $0.0102^{* * *}$ & $0.0067^{* * *}$ & $0.0119^{* * *}$ \\
\hline & $(0.0010)$ & $(0.0013)$ & $(0.0010)$ & $(0.0021)$ & $(0.0022)$ & $(0.0023)$ \\
\hline \multirow[t]{2}{*}{ Population } & $-0.0951^{* * *}$ & $-0.1466^{* * *}$ & $-0.1356^{* * *}$ & -0.0215 & 0.0243 & -0.0500 \\
\hline & $(0.0289)$ & $(0.0421)$ & $(0.0295)$ & $(0.0272)$ & $(0.0222)$ & $(0.0321)$ \\
\hline \multirow[t]{2}{*}{ Pvt. credit } & $0.0008^{* * *}$ & $0.0005^{*}$ & $0.0007^{* *}$ & $0.0016^{* * *}$ & 0.0005 & $0.0012^{* *}$ \\
\hline & $(0.0003)$ & $(0.0003)$ & $(0.0003)$ & $(0.0006)$ & $(0.0004)$ & $(0.0006)$ \\
\hline \multirow[t]{2}{*}{ KAOPEN } & 0.0025 & & & 0.0059 & & \\
\hline & $(0.0053)$ & & & $(0.0091)$ & & \\
\hline CAPITAL & & $\begin{array}{c}0.0007^{* *} \\
(0.0003)\end{array}$ & & & $\begin{array}{r}0.0017^{* * *} \\
(0.0005)\end{array}$ & \\
\hline FDI Inflow & & & $\begin{array}{r}0.0211^{* * * *} \\
(0.0048)\end{array}$ & & & $\begin{array}{r}0.0271^{* * *} \\
(0.0088)\end{array}$ \\
\hline Observations & 588 & 302 & 578 & 588 & 302 & 578 \\
\hline R-squared & 0.3562 & 0.2740 & 0.3606 & & & \\
\hline No. of countries & 105 & 74 & 108 & 105 & 74 & 108 \\
\hline
\end{tabular}

1. The dependent variable is the growth rate of TFP over each 5 -year period. 2 . All standard errors are robust and reported in parentheses. 3. Statistical significance: ${ }^{* * *} p<0.01,{ }^{* *} p<0.05,{ }^{*} p<0.1$. 4. Intercept not reported. 5. All regressions include time dummies. 6. For variables, see Table 1

growth of credit and the growth of TFP is also observed by Cecchetti and Kharroubi (2015).

\subsection{Extensions}

This study now extends the main analysis by examining the robustness of the basic findings using different alternative financial integration measures. As alternative de jure measure of financial integration, two popular openness indices-the Chinn-Ito index (KAOPEN) and the Quinn index (CAPITAL) - are used. Foreign direct investment (FDI) inflow as percentage of GDP is used as an alternative de facto measure of financial integration.

$\mathrm{KAOPEN}^{7}$ is an index that measures a country's level of capital account openness. In measuring KAOPEN, the authors use the information of capital account restriction, current account restriction, and foreign exchange restriction, and the surrender of export proceeds variables from the IMF's Annual Report on Exchange Arrangements and Exchange Restrictions (AREAER). A higher index value of KAOPEN indicates a higher level of capital account openness and less restriction. Similarly, the Quinn index (CAPITAL) is widely used in the literature of capital openness and argued though there are other attempts, the Quinn index is still one of the most reliant and popular indicators (Edwards 2001; Edison et al. 2002a). These indicators take a different approach in

\footnotetext{
${ }^{7}$ For detail calculation of KAOPEN, see Appendix 2 of Chinn and Ito's (2006).
} 
creating an index for a government's policy stance toward capital account liberalization and financial current account liberalization by offering a measurement not only of the existence (absence) of restrictions, but also the severity or magnitude of those restrictions (Quinn et al. 2008). This index is scored 0 to 4 , where 4 represents the economy that is fully open to capital flows.

In the first and second columns of each panel of Table 4, the coefficient of KAOPEN and CAPITAL is positive, thus implying that capital account openness is positively associated with higher TFP growth. The sign of both coefficients is per expectation that capital openness boosts up TFP growth though the coefficient of KAOPEN is not significant. The positive significant coefficient of alternative de facto measure (FDI inflow) implies that an increase of FDI inflows can cause higher TFP growth of an economy. So, our alternative measures support the basic findings.

\section{Conclusion}

Theoretically, opening the capital account facilitates a more efficient international allocation of resources. Policy makers and economists expect that, under desirable conditions, financial integration should promote economic growth by increasing investment and encouraging economic efficiency. Being motivated by the notion of prospective gains from financial integration, some developing country governments incorporate some form of capital account liberalization into their economic policies and have succeeded. However, there is also evidence that in spite of liberalized capital accounts, many countries have not been rewarded with higher growth and, rather, resulted in more instability. Moreover, current empirical studies have not reached any consensus regarding the impact of international financial integration on growth, which calls for the development of more sophisticated empirical research.

While a large amount of literature has examined the effects of financial integration on economic growth, mixed results are often found. It is important to know the channels through which the effect of integration operates. Different literature on growth suggests that if financial globalization affects the growth of nations, then it is more likely to do so through its impact on TFP, rather than factor accumulation. This paper focuses on the impact of financial integration on TFP growth, rather than output growth. A comprehensive empirical analysis is provided to study whether financial integration leads to higher TFP growth, using various measures and methods. In general, we find evidence showing that financial integration is associated with higher TFP growth. However, the result is sometimes a subtle one. The de jure measures of financial integration-all asset categories' composite restriction index (Ka), direct investment restriction index (Di), and Quinn index (CAPITAL) - show evidence that financial integration spurs TFP growth. The stocks of FDI liability and FDI net inflows as de facto measures of integration indicate strong evidence of contributing to TFP growth. These findings are robust to our attempts to deal with potential problems of endogeneity and reverse causality, leading us to the view that this may, in fact, be a causal relationship. These positive direct effects of financial integration on TFP growth can be explained as follows: the liberalization of restrictions to international financial transaction releases the access to trade in financial services, which can be considered as a production factor. As in trade models, integration generates gains from specialization and broadening of varieties, which raise 
efficiency in the allocation of capital in every country, thereby fostering TFP growth. As per the strong presumption, we find that FDI yields productivity gains. Domestic firms can realize these productivity gains through several channels, including the imitation or adoption of new production technology, skill acquisition by education/training of labor force, efficient use of existing resources, etc.

This paper also examines what roles financial development take in the relationship between financial integration and TFP growth. Findings of the interaction of capital control measure and financial development indicator suggest that the negative effect of capital control might be alleviated by high degree of financial development. Somewhat surprisingly, we find that financial development may reduce the effects of FDI on TFP growth. This finding, however, seems to be influenced by recent global economic turmoil and also by excessive private finance, especially in recent years. The implication of the result is that as consequences of financial crisis when an economy has attained a very high level of financial development (measured by private-sector credit), FDI flows do not enhance TFP growth. Instead, FDI flows hamper TFP growth when private credit is too high. Finance is found to promote growth, but it should not-regardless of the size and growth of the financial sector. The drastic declines in real sector activity during the crisis, due to adverse implications of financial instability, highlight the need for economists and policy makers to consider the optimal size of financial systems for sustainable economic growth (Law and Singh 2014).

The impact of financial integration on factor productivity growth may vary according to the level of income or economic development of an individual country. Determining whether the high-income countries have more potential to grasp the benefit of financial openness or the low-income developing countries are getting the advantage of relative backwardness is beyond the scope of this paper. Pursuing this issue in detail is left for future work.

In summary, our analysis using cross-country macroeconomic data fits into the growing research area that examines the relationship between international financial integration and TFP. The findings are consistent with micro-level facts that financial integration leads to important gains in productivity, especially when integration happens in the form of FDI. Compared to the cross-country analysis, micro-based firm-specific evidence yields better features on how productivity improves through integration. In this study, we only concentrate on the role of domestic financial development in the relationship between financial integration and TFP growth. However, in reality, many other domestic conditions can limit the degree at which financial integration impacts the economy. More prudent policies, especially for developing countries, might involve improving domestic conditions, which should have the dual effect of attracting foreign investment and facilitating host economies' exploitation of the benefits of such integration.

Acknowledgements

We would like to express our sincere gratefulness to Mr. Lee Kang-Kook (Professor, Graduate School of Economics, Ritsumeikan University) for his invaluable suggestions and insightful comments during the research work.

Authors' contributions

Both authors provided critical feedback and helped shape the research, analysis and manuscript. KI was involved in planning and supervised the work and AM processed the data, performed the analysis, and drafted the manuscript. Both authors discussed the results and commented on the manuscript. Both authors read and approved the final manuscript.

Funding

Partial funding from 'Grants-in-Aid for Scientific Research' provided by the Ministry of Education, Sports and Sciences. 
Availability of data and materials

The datasets analyzed during the current study available from the corresponding author on reasonable request.

\section{Competing interests}

It is to confirm that there are no known conflicts of interest associated with this study and there has been no significant financial support for this work that could have influenced its outcome.

Received: 30 April 2019 Revised: 29 February 2020 Accepted: 14 March 2020

Published online: 24 March 2020

\section{References}

Acemoglu D, Zilibotti F (1997) Was prometeus unbound by chance? risk, diversification and growth. J Political Econ 105:709-752

Agenor PR, McDermott CJ (2000) Macroeconomic fluctuations in developing countries: some stylized facts. World Bank Econ Rev 14(2):251-285

Aguiar M, Gopinath G (2007) Emerging market business cycles: the cycle is the trend. J Political Econ 115:69-102

Alfaro L, Kalemli-Ozcan S, Sayek S (2004) FDI and economic growth: the role of local financial markets. J Int Econ 64(1):89-112

Alfaro L, Kalemli-Ozcan S, Sayek S (2009) FDI, productivity and financial development. World Econ. 32(1):111-135

Arcand J-L, Berkes E, Panizza U (2012) Too much finance? International Monetary Fund, WP/12/161

Arteta C, Eichengreen B, Wyplosz C (2003) When does capital account liberalization help more than it hurts? In: Helpman E, Sadka E (eds) Economic policy in the international economy: essays in honor of Assaf Razin. Cambridge University Press, Cambridge

Azman-Saini WNW, Baharumshah AZ, Law SH (2010) Foreign direct investment, economic freedom and economic growth: international evidence. Econ Model 27(5):1079-1089

Baltabaev B (2014) FDI and total factor productivity growth: new macro evidence. World Econ 37(2):311-334

Barro R, Lee JW (2013) A new data set of educational attainment in the world, 1950-2010. J Dev Econ 104:184-198

Bekaert G, Harvey CR, Lundblad C (2011) Financial openness and productivity. World Dev 39(1):1-19

Blundell R, Stephen B (1998) Initial conditions and moment restrictions in dynamic panel data models. J Econometrics 87:115-143

Bonfiglioli A (2008) Financial integration, productivity and capital accumulation. J Int Econ 76(2):337-355

Borensztein E, De Gregorio J, Lee J (1998) How does foreign direct investment affect growth? J Int Econ 45(1):115-135

Carkovic M, Levine R (2005). Does Foreign Direct investment accelerate economic growth? in does foreign investment promote development? In: Moran TH, Graham EM, Blomstrom M (ed) Washington, Institute for International Economics)

Cecchetti SG, Kharroubi E (2015) Why does financial sector growth crowd out real economic growth BIS working papers. Bank of International Settlements, Switzerland

Chinn MD, Ito H (2006) What matters for financial development? Capital controls, institutions, and interactions. J Dev Econ 61(1):163-192

Chinn MD, Ito H (2008) A new measure of financial openness. J Comp Policy Anal. 10(3):309-322

Durham JB (2004) Absorptive capacity and the effects of foreign direct investment and equity foreign portfolio investment on economic growth. Eur Econ Rev 48(2):285-306

Dreher A (2006) Does globalization affect growth? Evidence from a new index of globalization. Appl Econ 38(10):1091-1110

Edison H, Levine R, Ricci L, Torsten S (2002a) Capital account liberalization and economic performance: survey and synthesis. NBER working paper. International Monetary Fund, Washington

Edison HJ, Levine R, Ricci L, SløkT (2002b) International financial integration and economic growth. J Int Money Fin. 21(6):749-776

Edison H, Klein M, Ricci L, Torsten S (2004) Capital account liberalization and economic performance: survey and synthesis. IMF Staff Papers 51(2):220-256

Edwards S, Levine R, Ricci L, Torsten S (2001) Capital mobility and economic performance: are emerging economies different? NBER Working Paper No. 8076. National Bureau of Economic Research, Cambridge, Massachusetts

Fernández A, Klein MW, Rebucci A, Levine R, Schindler M, Uribe M (2015) Capital control measures: a new dataset. IMF Working Paper No. 15/80. Inter American Development Bank, Washington

Fischer S (1998) Capital account liberalization and the role of the IMF. Should the IMF pursue capital-account convertibility? Essays in International Finance 207. Princeton University, Princeton, NJ, pp 1-10

Fischer S (2003) Globalization and its challenges. Am Econ Rev 93(2):1-30

Garita G (2009). How does financial openness affect economic growth and its components? Munch Personal Repec Archive, MPRA Paper no. 20099

Gehringer A (2013a) Financial liberalization, growth, productivity and capital accumulation: the case of European integration. Int Rev Econ Fin 25:291-309

Gehringer A (2013b). Financial liberalization, financial development and productivity Growth—an overview. Economics discussion Papers, No. 2013-46, Kiel Institute for the World Economy

Grilli Vittorio, Milesi-Ferretti Gian Maria (1995) Economic effects and structural determinants of capital controls. IMF Staff Papers 42(3):517-551

Gygli S, Haelg F, Potrafke N, Sturm JE (2019) The KOF globalisation index-revisited. Rev Int Organ 14(3):543-574

Hall RE, Jones Cl (1999) Why do some countries produce so much more output per worker than others? Q J Econ. 114(1):83-116

Henry PB (2007) Capital account liberalization: theory, evidence and speculation. J Econ Lit 45:887-935 
Feenstra RC, Inklaar R, Timmer MP (2015). The next generation of the Penn World Table. Forthcoming in American Economic Review

Gourinchas PO, Jeanne O (2007) Capital flows to developing countries: the allocation puzzle. NBER Working Paper No. 1360. Peterson Institute for International Economics, Washington

Klein M (2003a) Capital account openness and the varieties of growth experience. Working Paper Series No. 9500. MA NBER, Cambridge

Klein M (2003b) Capital account liberalization, institutional quality and economic growth: theory and evidence. NBER Working Paper No. 11112. National Bureau of Economic Research, Cambridge, Massachusetts

Klenow PJ, Rodriguez-Clare A (1997) The neoclassical revival in growth economics: Has it gone too far? NBER Macroecon Annu. 12:73-103

Kose MA, Prasad ES, Terrones ME (2008a) Does openness to international financial flows raise productivity growth? IMF Working Paper 08/242. International Monetary Fund, Washington

Kose MM, Ayhan EP, Taylor Ashley (2008b) Thresholds in the process of financial integration. J Int Money Fin 30:147-179

Kraay A (1998) In search of the macroeconomic effects of capital account liberalization. World Bank, Washington

Lane PR, Milesi-Ferretti GM (2018) The external wealth of nations revisited: international financial integration in the aftermath of the global financial crisis. IMF Econ Rev. 66(1):189-222

Lane PR, Milesi-Ferretti GM (2007). The external wealth of nations mark II: revised and extended estimates of foreign assets and liabilities, 1970-2004. IMF Working Paper 06/69

Law SH, Singh N (2014) Does too much finance harm economic growth? J Banking Finance. 41:36-44

Lee K-K (2016) Capital account liberalization and economic growth: the empirical relationship revisited. Ritsumeikan Econ Rev 64(3):247-262

Levchenko AA, Rancière R, Thoenig M (2009) Growth and risk at the industry level: the real effects of financial liberalization. J Dev Econ 89(2):210-222

Loayza N, Ranciere R (2006) Financial development, financial fragility, and growth. J Money Credit Banking 38(4):1051-1076

O'Donnell B (2001). Financial openness and economic performance. (Unpublished; Trinity College, Dublin)

Obstfeld M (1998) The Global capital market: benefactor or menace? J Econ Perspect 12(4):9-30

Prasad E, Rajan R, Subramanian A (2007) Foreign capital and economic growth. Brookings Pap Econ Act 2007(1):153-209

Quinn Dennis (1997) The correlates of changes in International Financial Regulation. Am Political Sci Rev 91:531-551

Quinn D, Maria Toyoda A (2008) Does capital account liberalization lead to growth? Rev Financial Stud 21(3):1403-1449

Rodrik D (1998) Who needs capital-account convertibility? in essays in international finance, vol 207. Princeton, Princeton University, New Jersey

Rogoff K (1999) International institutions for reducing global financial instability. J Econ Perspect 13(4):21-42

Schindler M (2009) Measuring financial integration: a new data set. IMF Staff Papers 56(1):222-238

Stiglitz J (2000) Capital market liberalization, economic growth, and instability. World Dev 28(6):1075-1086

Summers LH (2000) International financial crises: causes, prevention, and cures. Am Econ Rev 90(2):1-16

Vanassche E (2004) The impact of international financial integration on industry growth'. Manuscript. Katholieke Universiteite Leuven, Belgium

Voth HJ (2003) Convertibility, currency controls and the cost of capital in Western Europe, 1950-99. Int J Finance Econ 8:255-276

Woo J (2009) Productivity growth and technological diffusion through foreign direct investment. Econ Inq 47(2):226-248

\section{Publisher's Note}

Springer Nature remains neutral with regard to jurisdictional claims in published maps and institutional affiliations.

\section{Submit your manuscript to a SpringerOpen ${ }^{\circ}$ journal and benefit from:}

- Convenient online submission

- Rigorous peer review

- Open access: articles freely available online

- High visibility within the field

- Retaining the copyright to your article

Submit your next manuscript at $\boldsymbol{\nabla}$ springeropen.com 